
\title{
R Resercrch Suare \\ The Effectiveness Of Application Of The Leadership Style And Entrepreneurial Orientation To Improve Business Performance
}

Budi Alamsyah Siregar ( $\sim$ siregarbas@upmi.ac.id)

Universitas Pembinaan Masyarakat Indonesia

Research

Keywords: Transformational Leadership, Entrepreneurial Orientation, Medium Size Enterprises.

Posted Date: September 22nd, 2020

DOI: https://doi.org/10.21203/rs.3.rs-81381/v1

License: (c) (1) This work is licensed under a Creative Commons Attribution 4.0 International License.

Read Full License 


\section{Abstract}

An owner's leadership style determines how the company carries out the activities in achieving its performance. The entrepreneurial orientation behavior present in an owner also determines how higher business performance can improve success. This study aims to understand how the role of a manager's leadership style and entrepreneurial orientation in improving his business performance. This research used a qualitative Delphi method by collecting in-depth data from 20 company owner. The results indicate the owner's transformational leadership style, a group of medium-sized enterprises that have developed and are beginning to be established, directly determines the applied entrepreneurial orientation. Finally, the application can affect the performance of the business. Behavior entrepreneurial orientation; not only promotes business growth medium, but it can also affect large enterprises' profitability due to the indirect impact achieved by large companies through cooperation in the supply of raw materials for products. The impact of increasing innovation power, proactive power, and risk-taking power on business performance arise from the support of a transformational leadership style. When transformational leadership styles and entrepreneurial orientations combine, medium-sized enterprises will achieve higher performance.

\section{Introduction}

At present, various businesses are always facing changes in their complex and dynamic environment, which impact high competition. In this context, entrepreneurship is a means of choice that can be applied and can create sustainability and increase business growth. In a broader sense, the phenomenon that occurs from this dynamic change is considered never to stop and continues to direct the owner always to strive to find, evaluate, and exploit opportunities for new businesses (Shane \& Venkataraman, 2000).

Recognition of these opportunities includes activities check the external environment for gain new markets, opportunities to complement the needs of consumers of non-fulfilled, repair problems already in the process of work, and foster the birth of ideas in creating a new product.

In this case, businesses with entrepreneurial behavior show that they have achieved greater profitability and growth than businesses that do not adopt entrepreneurship (Antoncic, 2007). As the effects that appear, the behavior of entrepreneurship at the moment, be an attitude that is permanently held by an owner in developing and trying to improve business growth. However, the behavior of entrepreneurial orientation can not be from the company's owner's leadership style.

Since the 1970s, strategic orientation behavior in developing business has become a significant concept in entrepreneurship studies. The business's strategic orientation includes aspects of a leader's decisionmaking style, methods, and practices (Wiklund \& Shepherd, 2005). As a policy proponent, business leaders are also responsible for making strategic decisions. Owners will play an essential and dominant role during the formula's application and implement the implementation of the company's strategic orientation. 
A leader who can effectively suitably influence his followers is to achieve his goals. Therefore, the application of a leadership style can influence improving business performance (Nahavandi, 2009). Based on several previous studies, it shows the need to integrate the concept of applying leadership style with entrepreneurial orientation behavior. The alignment is right at the birth of the concept of entrepreneurial leadership to explore the behavior of leadership and entrepreneurship (Fernald et al., 2005; House et al., 2004).

Results of research, attempting to integrate entrepreneurship into leadership entrepreneurial leadership (entrepreneurial leadership). The model of the development of new leadership is used to show entrepreneurial behavior and leadership (Fernald et al., 2005). The competitive environment in which dynamic, complex, and uncertain at this time, the type of application of an entrepreneurial leader is different from the usual indispensable (Neck et al., 2004).

The phenomenon related to the problem of entrepreneurial leadership is exciting to study. However, there is not much research related to this issue. In particular, it provides a study on the application of entrepreneurial leadership in the types of middle to lower enterprises in Indonesia.

Based on this, this study aims to understand how the role of the application of leadership style and entrepreneurial orientation behavior can improve a business's performance. The results of this research will later contribute to the development of new knowledge and understanding in the study of leadership and entrepreneurship, especially entrepreneurial leadership.

\section{Literature Review}

Research on entrepreneurial orientation behavior is currently increasing rapidly in various fields. These studies reflect efforts to fill gaps in the literature on entrepreneurship studies. Consequently, much research on entrepreneurial orientation has led to recognizing entrepreneurial orientation behavior as a significant form in the strategic management field and entrepreneurial literature (Morris \& Kuratko, 2002).

\section{Leadership Style}

Organizational activities such as information gathering and processing within the company affect decision-making processes, practices, and activities, which lead to the creation of new businesses (Bouchard \& Basso, 2011). These managerial activities form what is known as a leadership style.

Leadership style is a relatively consistent pattern of behavior that shows a leader (DuBrin, 2013). Organizations today's dynamic changing environment need influential leaders who can understand the rapidly changing global environment's complexities. Applying a leadership style that is different from others can affect company performance (Nahavandi, 2009).

This study focuses on the application of a transformational leadership style. This leadership concept has been fundamental in the leadership literature in the past few years (Avolio et al., 2004). 
This research conducted did not examine the application of transactional leadership styles. It is because, in general, transformational leadership is more effective than transactional leadership (Gardner \& Stough, 2002). This research found data that supported the conclusion that transformational leadership is superior to transactional leadership (Bouchard \& Basso, 2011). Transformational leadership is more substantial than transactional leadership in increasing and achieving higher productivity and performance (Lowe et al., 1996).

In the face of dynamic changes like today, applying an effective transformational leadership style (Yukl, 2013). Applying a transformational leadership style is best suited to explain the relationship between entrepreneurial orientation behavior in improving company performance, especially in the medium enterprise. Leadership transformational is a leader who always behaves to achieve the other's superior, emphasizing aspects of applying transformational leadership (Avolio et al., 2004).

First, leadership is idealized. In this section, employees always try to identify themselves with their leader's style and try to adapt it. If a medium-sized business leader always displays strong personal values combined with his charisma, they will integrate them into themselves. Besides, employees will try to match these morals and ethics in coping with other employees (Zhang \& Howell, 2011). In this case, transformational leaders will influence employees' entrepreneurial attitudes and behavior and business activities' effectiveness.

Second, leadership inspires employees by providing information about challenges that aim to provide an understanding of the circumstances experienced. Transformational leaders in medium-sized businesses encourage changes in employee entrepreneurial attitudes and behaviors to improve personal performance to exceed expectations.

A transformational leader will encourage the creation of innovation, creating change, and creating achievement of the high expectations of the changes made. Besides, transformational leaders will build team spirit, featuring the spirit and optimism, and involve employees in envisioning the achievement of a state of an exciting future together.

Transformational leaders try to speed up the development of a collective identity to in together, encourage strong interpersonal bonds, and communicate expectations to be met by employees in meeting the company's objectives.

Third, transformational leadership is intellectually stimulating. Transformational leaders, always trying to expand and improve employee capabilities. They will influence the orientation of employees' entrepreneurial attitudes and behaviors by encouraging deep intellectual processing, questioning existing norms, concepts, practices, and processes for continuous improvement. They also encourage employees to approach old problems in new ways by encouraging and driving change.

Fourth, leadership has a humble behavior individually. Transformational leaders, providing support to employees, mentoring, and training. They will influence the attitude orientation and entrepreneurial 
behavior of employees. Transformational leaders currently personalize interactions with employees, carry out by way of listening effectively, identify the different needs and desires, and behave in ways that indicate acceptance of differences among employees. They delegate tasks based on the ability and quality of employees (Walumbwa et al., 2010).

Transformational leaders motivate employees to overcome their interests to put their good interests, organization, or society. The explanation above shows that transformational leaders will generally articulate a new vision, mission, and goals to motivate their employees and show high enthusiasm and confidence in their beliefs.

They inspire employees to transcend self-interest and focus on collective goals, driving commitment, effort, and performance. Mid-sized businesses will broaden employees' aspirations, motivations, goals, and values by acting as role models that display high moral and ethical behavior standards. Values that reflect this transformational leadership style tend to support entrepreneurial orientation behavior in developing and established medium-sized enterprises.

\section{Entrepreneurial Orientation}

Entrepreneurial orientation is the central concept in understanding whether companies adopt entrepreneurial activities or not. This orientation emphasizes the use of opportunities by developing new ways of carrying out business activities. In Miller (1983) and Miller and Friesen (1983), entrepreneurial orientation is innovation, proactive power, and risk-taking.

Many studies then applied and developed this dimension as a basis for their investigations such as Covin and Slevin (1991) and Covin et al. (2006), Kreiser et al. (2002), Lumpkin and Dess (1996), and Fernald et al. (2005). This entrepreneurship dimension is essential for understanding the entrepreneurial process at the company level (Antoncic \& Hisrich, 2003).

Entrepreneurial orientation indicates a standard measure used in the literature on entrepreneurship studies. The entrepreneurial orientation emphasizes the aspects of entrepreneurial presence at the company level (Wiklund \& Shepherd, 2005).

The entrepreneurial orientation assumption shows that businesses that emphasize entrepreneurial aspects are different from other types of businesses. Entrepreneurship in a successful company must have an entrepreneurial orientation (Wiklund \& Shepherd, 2003). This study compares the dimensions of entrepreneurial orientation with firm performance.

Entrepreneurial orientation refers to decision making, which is related to its strategy to start building innovation, proactive power, and risk-taking (Lumpkin \& Dess, 1996). First, innovation-power is the readiness to support creativity and experimentation in introducing new products or services and new processes. 
Innovation is one of the dimensions of entrepreneurial orientation by introducing new products or service processes or technology. Innovation includes both the rate and frequency of innovation within the company. A limited allocation of resources to innovative activities was as its most significant obstacle to innovation.

A company that began to grow and established by adopting the power of innovation aims to achieve growth by developing new products. Companies that can offer various products and good technology support will get a more significant financial benefit. An innovative strategic attitude is to positively impact company performance in creating new market opportunities and creating new products, services, and processes innovatively.

Second, proactive power is the readiness to develop ideas from emerging opportunities through research, analysis, and forecasting market trends. This attitude is a manifestation of the effort to lead the market rather than follow the aggressive competition. With proactive power, the company can create market opportunities by creating the best strategy to compete in the business world-companies trying to anticipate and meet the markets' needs and demands recently.

The ability to anticipate problems, complete needs, or change in the future allows the company to shape the environment and direction of competition. The more proactive the company can develop an aggressive movement in seizing new business opportunities, the greater the growth rate.

Third, risk-taking is another crucial dimension of entrepreneurial orientation. This attitude consists in accepting risks associated with investing and strategic decisions, although the outcome of these actions is uncertain. This concept also means the ability to control and evaluate risk. With the courage to take risks, companies can seize new market opportunities and allocate considerable resources with little knowledge of the new market situation.

The positive effect of risk-taking on company performance shows that companies with the incentive to allocate considerable resources to high-risk projects have the advantage of increasing company revenues.

This study seeks to combine two concepts, namely, leadership and entrepreneurship. The aim is to examine how leadership can influence entrepreneurial orientation. Entrepreneurial leadership is a useful and necessary leadership style (Fernald et al., 2005), especially for people who realize that a leadership style change is necessary.

Entrepreneurial leaders play an essential role in the success of new businesses. This study assumes that a combination of transformational leadership style and entrepreneurial orientation can improve company performance.

\section{Method}


This research was a qualitative approach through the Delphi method. This method to understand in-depth how the leadership style has been, the entrepreneurial orientation that is the role of improving company performance directly from several expert sources in the companies studied.

The research data consists of two types: primary data obtained directly from the field and secondary data obtained from documents. The data of this research were collected using survey techniques and Delphi techniques.

The survey on company owners from several companies operating in the same sector. In-depth interviews, researchers conducted with company owners to reveal various information in more detail.

Researchers carried out this activity to help carry out exploratory activities from the collected data if they had difficulty gathering sufficient evidence following the conceptual research framework. To achieve the research objectives, researchers applied the Delphi method (Linstone \& Turoff, 1975).

This method aims to form an understanding of the research topic by collecting data from various information with in-depth case evidence from experienced expert respondents, especially 20 experts among the company owners concerned.

The Delphi method is a systematic, interactive method of estimation, relying on independent experts' panel. This method is on the principle that the viewpoints of a structured group of experts are much more accurate than the points of view obtained from an unstructured group of people (Linstone \& Turoff, 1975).

The purpose of data collection in the Delphi research method is to encourage research participants to improve their previous answers from other members of the selected panel team's responses. As long as this process, the various answers' distance will decrease and converge towards the accurate answers.

One of this study's essential objectives is to understand the leadership style and entrepreneurial orientation in improving company performance. The Delphi process allows researchers to understand the expert panel that comes from within the company itself.

In data collection, Delphi's study followed the four-phase procedure of Kasi et al. (2008), where the panel reviewed the resulting list and initial interpretation of the results. First, validation and expansion. A list of leadership style indicators, entrepreneurial orientation, and company performance show to the panelists for validation. Panelists to add missing items, then new items were combined and grouped.

Second, improvement. Each panelist selects the items that are least observed. The items selected by the majority of the panelists were. It reduces the list of indicator items of the three variables under study. Third, ranking. Each panelist ranked the order based on observations about leadership style, entrepreneurial orientation, and company performance. 
Feedback, divided on the panelists who ranked the items back based on their observations about these variables. The process continues until it finds an agreement. Fourth, reflection. Panelists were to provide descriptive support for the items selected based on the cases experienced. It explains the differences in leadership styles, entrepreneurial orientation, and company performance. This phase seeks validation and feedback on the patterns found.

\section{Result And Discussion}

\section{Research result}

This research was conducted on 20 developing Medium Enterprises (UM) in Yogyakarta. This company is engaged in various sectors, both producing goods, and services. Most of them have started to open branches or penetrate the national market or even export with the addition of variations in products or services. The results of this study indicate that most companies show a positive effect of leadership style and entrepreneurial orientation in improving company performance.

Table 1 shows that the leadership style, entrepreneurial orientation, and company performance are the most widely understood by company expert participants. The leadership style applied is transformational leadership. The entrepreneurial orientation has a lot to do with innovation-power, pro-action-power, and risk-taking. Finally, the company's performance has a lot to do with overall profitability. They were mainly related to investment returns, asset gains, and sales profits.

Table 1

Leadership Style and Entrepreneurial Orientation in Improving the Company's Business Performance

\begin{tabular}{|c|c|c|}
\hline Leadership Style & Entrepreneurial Orientation & Company performance \\
\hline $\begin{array}{l}\text { - Leaders display strong personal } \\
\text { values. It affects the orientation of } \\
\text { employees' entrepreneurial behavior } \\
\text { as well as the overall effectiveness } \\
\text { of their business. } \\
\text { - Leaders inspire and influence } \\
\text { entrepreneurial orientation by } \\
\text { encouraging innovation, creating } \\
\text { change, and building high } \\
\text { expectations. } \\
\text { - Leaders influence entrepreneurial } \\
\text { orientation by encouraging deep } \\
\text { intellectual processing to approach } \\
\text { old problems in new ways that lead } \\
\text { to change. } \\
\text { Leaders seek to personalize } \\
\text { interactions with employees by } \\
\text { listening effectively, identifying } \\
\text { different needs and wants, and } \\
\text { motivating them to address self- } \\
\text { interests for the organization's good. }\end{array}$ & $\begin{array}{l}\text { Power-innovation: } \\
\text { - Oriented to achieve growth } \\
\text { - Improve management as it grows } \\
\text { - Developing new products with incremental changes in the current } \\
\text { product line. } \\
\text { - Introducing novelty into the market } \\
\text { - Engage in intense competition in today's global economy. } \\
\text { - Increase the ability to offer product lines with technical support in the } \\
\text { organization } \\
\text { - Always create market opportunities and innovative new products, } \\
\quad \text { services, and processes. } \\
\text { Power-proactive } \\
\text { - Become a pioneer by creating new market opportunities } \\
\text { - Always be the first to introduce new products or services for brand } \\
\text { recognition } \\
\text { - Always anticipate needs and demands in new markets } \\
\text { - Build the ability to anticipate problems, needs, or changes in the future } \\
\text { Trying to respond aggressively to competitors } \\
\text { Risk-taking } \\
\text { - Large resource allocation } \\
\text { - Seize new market opportunities and allocate massive resources in new } \\
\text { market situations. } \\
\text { - Allocating massive resources on high-risk projects with high returns }\end{array}$ & $\begin{array}{l}\text { Overall } \\
\text { profitability } \\
- \text { Investment benefits } \\
-\quad \text { Short-term } \\
-\quad \text { Medium-term } \\
-\quad \text { Long-term } \\
\text { Asset gain } \\
-\quad \text { Fixed assets } \\
\text { - Movable assets } \\
\text { Sales profit } \\
\text { - Retail sales } \\
\text { - Sales agency }\end{array}$ \\
\hline
\end{tabular}

Source: Processed from primary data (2020)

Innovation in ME's was positively related to overall profitability, and objective measures of firm performance are related to return on investment, return on assets, and return on sales. Also, companies that are beginning to grow bigger and more established are always to adopt innovations to achieve 
growth by developing new products that drive incremental changes in existing product lines. Introducing novelty into the market, it is evident among ME's, helps understand the intense competition from today's global economy.

In this case, the company that can offer various product lines and good technology support in the organization will get a more significant financial advantage. Therefore, this study's results indicate that an innovative strategic attitude is to impact company performance positively. In particular, creating new market opportunities and creating new products, services, and processes innovatively.

Furthermore, this study's results indicate that a pro-active company has the advantage of its pioneering status. It is because the company can take advantage of and create opportunities in the market. Among the MEs studied, there is a tendency that proactive power is the best strategy to compete in the business world. When introducing a new product or service, a company can earn extraordinarily high finances and have a great head start establishing brand recognition. Being the first company to introduce a product or service will result in high customer loyalty.

This study's informants indicate that companies that want to develop the need to be pro-active, especially to anticipate the needs and demands in new markets. The ability to anticipate problems, the need for change in the future allows the company to shape the environment and direction of competition for its benefit.

The results of this study also show that companies are proactive, not only proactive in pursuing opportunities, but also in responding aggressively to competitors. This behavior allows a company to compete with competitors and obtain superior company performance. The more proactive the company is in developing an aggressive movement to seize new business opportunities, the greater the growth rate as found among ME's in this study.

Finally, risk-taking is significant for the business performance of MEs in this study. This risk-taking attitude refers to a tendency to move from a predictable situation to a position where it can seize new market opportunities and allocate considerable resources with little knowledge of the new market situation. The results of this study indicate that the dimensions of risk-taking are positively related to company performance. Some informants argued that the positive effect of risk-taking on company performance was that companies with the incentive to allocate considerable resources to high-risk projects with high returns would have the advantage of increasing company revenues.

\section{Discussion}

The emergence of the digital era is developing an economy based on knowledge and information technology amid increasingly intense global competition. In such a context, medium-sized businesses begin to grow and develop and solidify their development into companies ready to seize new markets, either on a national or international scale. 
Middle-scale companies are to face intense global competition by developing new methods, techniques, processes, products, or services with each other, and they seek to seize and maintain market share. In such a context, companies have a more entrepreneurial spirit with an innovative and proactive attitude and are willing to take risks in allocating considerable resources. They strive to achieve a competitive advantage that will differentiate them from competitors and maintain a sustainable, profitable position in a given market share.

Medium-sized business owners who have grown into relatively well-established companies show great interest in entrepreneurial orientation. A strong indicator of this entrepreneurial interest is the increase in new businesses' formation; both engaged in producing products and services and behaving with entrepreneurial principles in established companies.

Simultaneously, the owners of the middle-class companies that established, tending to promote and promote the entrepreneurial spirit in their companies. It means a company has grown from a young age and is starting to be established, with an entrepreneurial spirit, encourages its employees to be entrepreneurial. This drive is evident in almost all companies, reflecting a transformational leadership style.

The results showed that the transformational leadership style applied by the owners of medium-sized businesses that were developing and becoming established led to the emergence of an entrepreneurial orientation at the company level. The company's strategic processes are always to innovate, be proactive, and dare to take risks. Based on this, companies with an entrepreneurial orientation tend to innovate continuously, act proactively, and make riskier investments.

In general, they aim to achieve growth, improve management practices, developments, and continuously develop new products. In essence, they always try to introduce novelty in the market, involve themselves in intense competition in the global economy, increase the ability to offer products with the support of the technology used, and always create market opportunities and innovative new products and processes.

Such indicators of entrepreneurial orientation are in companies that are researched and agreed upon by their respective owners. This entrepreneurial orientation cannot be from the application of a transformational leadership style.

Furthermore, along with the increasing entrepreneurial orientation of these developing and established companies' owners, it was found that company performance also appeared to be developing. It shows that the development of entrepreneurial orientation in a company is beneficial for achieving company performance, as shown by Rauch et al. (2009).

However, this company's relationship, entrepreneurial orientation, and performance depend on each company's contexts and environments. Services companies tend to develop in the region. While the product-based company tends to develop into a market share National program or even the International. 
However, in any context and environment, the applied transformational leadership style tends to be more flexible. The application of an entrepreneurial orientation prioritizes the application of innovation power, proactive strength, and the courage to take investment risks that impact improving company performance, both in the short, medium, and long term.

Initially, by adopting an entrepreneurial orientation, the companies studied tended to appear to be implementing business strategies and implementations that were costly and required large investments.

However, adopting a transformational leadership style that emphasizes continuous innovation and proactive power and is willing to take risks with investments tends to generate substantial returns. This advantage can be short-term, medium-term, and long-term investment benefits. These gains led to increased asset profits, both fixed and movable assets, and sales gains, both retail and agency.

The results of this study found that in a context and environment characterized by intense competition, transformational leadership style, and entrepreneurial orientation are positively related to company performance.

This study proves the research results by Covin et al. (2006) that entrepreneurial orientation is positively related to business performance. Following the literature reviewed Wiklund and Shepherd (2005), this study's findings indicate that entrepreneurial orientation at high levels positively contributes to business performance.

A comparison of the three dimensions of entrepreneurial orientation shows that the level of innovation, proactive and risk-taking positively contributes to business performance. However, it should be that although the risk-taking is an attribute of the entrepreneurial, successful entrepreneurs are not gamblers speculative. Successful entrepreneurs usually taking a risk by calculating calculations carefully and avoid unnecessary risks, as suggested by Begley and Boyd (1987). The relationship between risk-taking and business performance may differ from other factors, such as the environment (Krauss et al., 2005).

Also, the application of leadership styles that differ turned out to affect the performance of the business. Implementation leadership transformational is significantly associated with the business's performance rather than the application of transactional leadership. Two leadership styles are the better transformational leadership in contributing to the company's performance rather than transactional leadership.

This study supports the results of Gardner and Stough (2002), which explain that transformational leadership is more effective than transactional leadership. The leadership style has a more substantial impact on producing higher company productivity and performance (Bass et al., 2003). Finally, applying a transformational leadership style and a high entrepreneurial orientation can contribute to high company performance. This study supports a new concept of entrepreneurial leadership, which is more transformational than transactional (Thornberry, 2006). 


\section{Conclusion}

The results of this study indicate that applying different leadership styles can determine the company's entrepreneurial orientation, and in turn, it can affect company performance. Transformational leadership is more oriented towards entrepreneurship than transactional leadership, and if the transformational leadership style and entrepreneurial orientation chime, the company achieves higher performance.

This study concluded that among MEs, entrepreneurial orientation has a positive impact on company performance. In this case, the entrepreneurial orientation that is applied is not only crucial for many medium-sized companies that are developing for the sake of continuity and growth but can also affect the profitability of large companies. This study found that entrepreneurial orientation dimensions of innovation-power, proactive power, and risk-taking power positively affect firm performance. This influence by the application of a transformational leadership style.

\section{Abbreviations}

UM: Medium Enterprises.

\section{Declarations}

\section{Acknowledgements:}

The author deeply acknowledges the cooperation of the Springer Waiver Resolution Team.

\section{Author's contributions:}

I have contributed fully to this manuscript. The author has read and approved the final manuscript text.

\section{Funding:}

The author does not have a funding agency to complete this manuscript.

\section{Availability of data and materials:}

The author uses open data issued by the Yogyakarta Government (http://www.bappeda.jogjaprov.go.id) and company owners' primary data.

\section{Competing interests:}

The author states that he has no conflict of interest with others in completing this manuscript.

\section{References}


Antoncic, B. (2007). Intrapreneurship: a comparative structural equation modeling study. Industrial Management \& Data Systems.

Antoncic, B., \& Hisrich, R. D. (2003). Clarifying the intrapreneurship concept. Journal of Small Business and Enterprise Development.

Avolio, B. J., Bass, B. M., \& Zhu, F. W. W. (2004). Multifactor leadership questionnaire: manual and sampler set. Mind Garden, Incorporated.

Bass, B. M., Avolio, B. J., Jung, D. I., \& Berson, Y. (2003). Predicting unit performance by assessing transformational and transactional leadership. Journal of applied psychology, 88(2), 207.

Begley, T. M., \& Boyd, D. P. (1987). Psychological characteristics associated with performence in entrepreneurial firms and smaller businesses. Journal of business venturing, 2(1), 79-93.

Bouchard, V., \& Basso, O. (2011). Exploring the links between entrepreneurial orientation and intrapreneurship in SMEs. Journal of Small Business and Enterprise Development, 18(2), 219-231.

Covin, J. G., Green, K. M., \& Slevin, D. P. (2006). Strategic process effects on the entrepreneurial orientation-sales growth rate relationship. Entrepreneurship theory and practice, 30(1), 57-81.

Covin, J. G., \& Slevin, D. P. (1991). A conceptual model of entrepreneurship as firm behavior. Entrepreneurship theory and practice, 16(1), 7-26.

DuBrin, A. J. (2013). Handbook of research on crisis leadership in organizations: Edward Elgar Publishing.

Fernald, L. W., Solomon, G. T., \& Tarabishy, A. (2005). A new paradigm: Entrepreneurial leadership. Southern business review, 30(2), 1-10.

Gardner, L., \& Stough, C. (2002). Examining the relationship between leadership and emotional intelligence in senior level managers. Leadership \& organization development journal.

House, R. J., Hanges, P. J., Javidan, M., Dorfman, P. W., \& Gupta, V. (2004). Culture, leadership, and organizations: The GLOBE study of 62 societies: Sage publications.

Kasi, V., Keil, M., Mathiassen, L., \& Pedersen, K. (2008). The post mortem paradox: a Delphi study of IT specialist perceptions. European journal of information systems, 17(1), 62-78.

Krauss, S. I., Frese, M., Friedrich, C., \& Unger, J. M. (2005). Entrepreneurial orientation: A psychological model of success among southern African small business owners. European journal of work and organizational psychology, 14(3), 315-344.

Kreiser, P. M., Marino, L. D., \& Weaver, K. M. (2002). Assessing the psychometric properties of the entrepreneurial orientation scale: A multi-country analysis. Entrepreneurship theory and practice, 26(4), 
71-93.

Linstone, H. A., \& Turoff, M. (1975). The delphi method: Addison-Wesley Reading, MA.

Lowe, K. B., Kroeck, K. G., \& Sivasubramaniam, N. (1996). Effectiveness correlates of transformational and transactional leadership: A meta-analytic review of the MLQ literature. The leadership quarterly, $7(3)$, 385-425.

Lumpkin, G. T., \& Dess, G. G. (1996). Clarifying the entrepreneurial orientation construct and linking it to performance. Academy of management review, 21(1), 135-172.

Miller, D. (1983). The correlates of entrepreneurship in three types of firms. Management science, 29(7), 770-791.

Miller, D., \& Friesen, P. H. (1983). Strategy-making and environment: the third link. Strategic management journal, 4(3), 221-235.

Morris, M. H., \& Kuratko, D. F. (2002). Corporate entrepreneurship: Entrepreneurial development within organizations: South-Western Pub.

Nahavandi, A. (2009). The art and science of leadership: Pearson Prentice Hall Upper Saddle River, NJ.

Neck, H. M., Meyer, G. D., Cohen, B., \& Corbett, A. C. (2004). An entrepreneurial system view of new venture creation. Journal of small business management, 42(2), 190-208.

Rauch, A., Wiklund, J., Lumpkin, G. T., \& Frese, M. (2009). Entrepreneurial orientation and business performance: An assessment of past research and suggestions for the future. Entrepreneurship theory and practice, 33(3), 761-787.

Shane, S., \& Venkataraman, S. (2000). The promise of entrepreneurship as a field of research. Academy of management review, 25(1), 217-226.

Thornberry, N. (2006). Lead like an entrepreneur. McGraw Hill Professional.

Walumbwa, F. O., Hartnell, C. A., \& Oke, A. (2010). Servant leadership, procedural justice climate, service climate, employee attitudes, and organizational citizenship behavior: a cross-level investigation. Journal of applied psychology, 95(3), 517.

Wiklund, J., \& Shepherd, D. (2003). Knowledge-based resources, entrepreneurial orientation, and the performance of small and medium-sized businesses. Strategic management journal, 24(13), 1307-1314.

Wiklund, J., \& Shepherd, D. (2005). Entrepreneurial orientation and small business performance: a configurational approach. Journal of business venturing, 20(1), 71-91. 
Yukl, G. (2013). Leadership in organisations. University of Albany, State University of New York. In: Pearson Global Edition.

Zhang, J. W., \& Howell, R. T. (2011). Do time perspectives predict unique variance in life satisfaction beyond personality traits? Personality and individual differences, 50(8), 1261-1266.

\section{Figures}

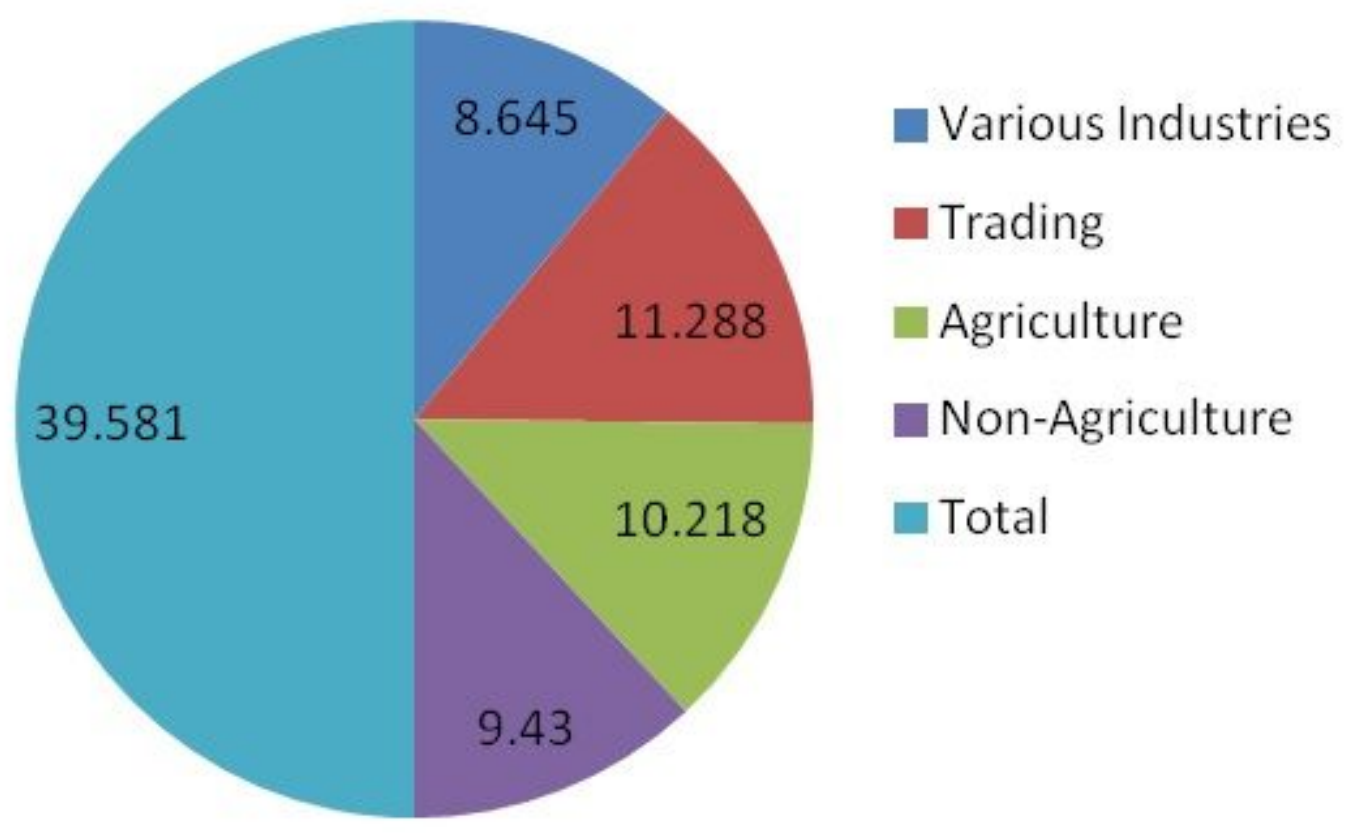

Source: Bappeda Yogyakarta, Indonesia (2020)

\section{Figure 1}

Data on the Development of Medium Enterprises in Yogyakarta 2019 


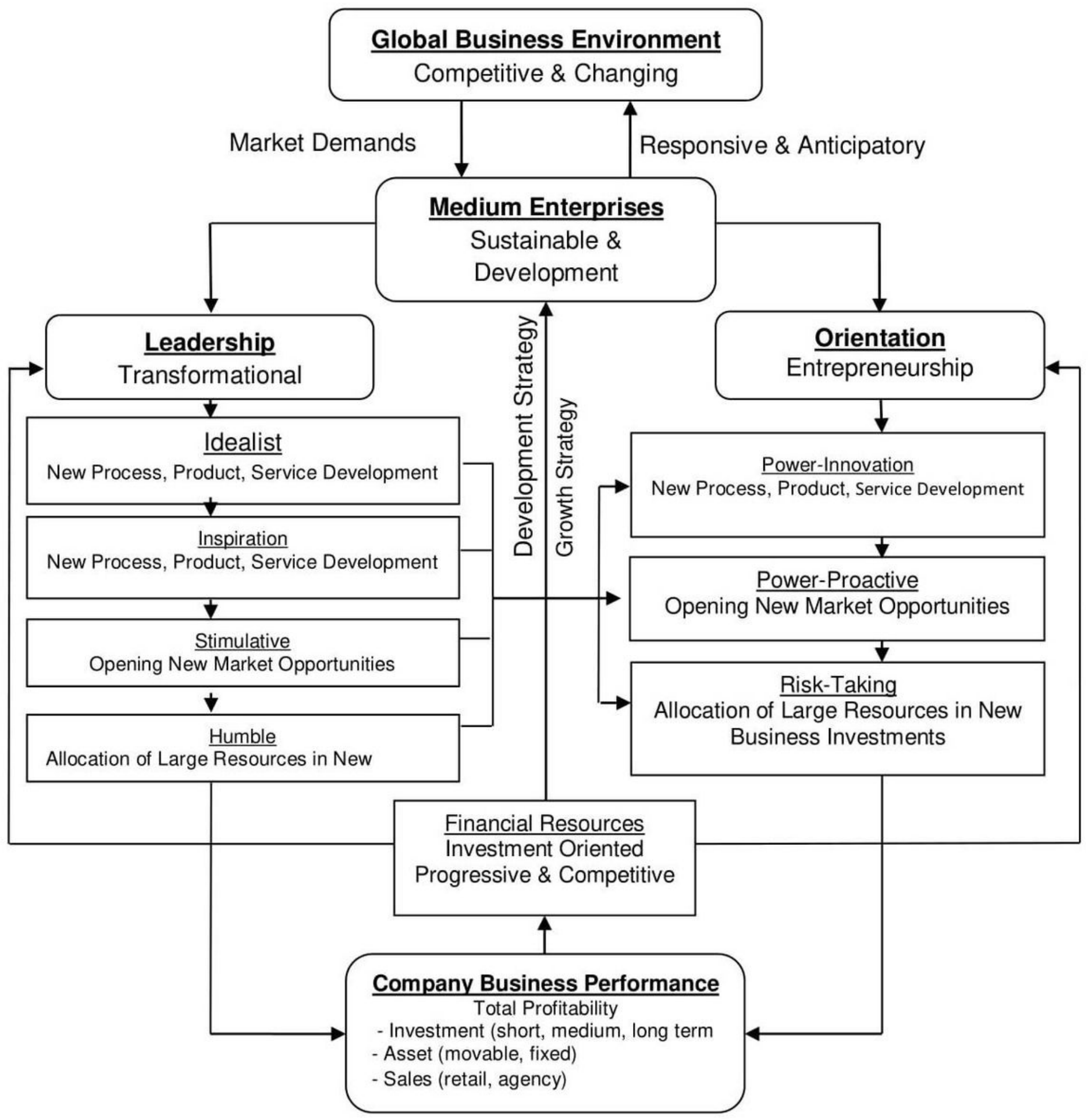

Figure 2

Transformational leadership style and entrepreneurial orientation in improving company performance 